\title{
Peripheral Blood Smears in COVID-19: A Comment
}

\author{
Periferik Kan Yaymasında COVID-19: Bir Yorum
}

(D) Rujittika Mungmunpuntipantip1, (D) Viroj Wiwanitkit2

1 Private Academic Consultant, Bangkok, Thailand

2Joseph Ayobabalola University, Ikeji-Arakeji, Nigeria

\section{To the Editor,}

We would like to share our ideas on the recently published letter entitled "Peripheral Blood Smear Findings in COVID-19" [1]. Ahnach et al. [1] reported several observations and concluded that "Our preliminary results remain limited and more investigation is required to study the reversibility of these abnormalities and their impact on severity. Compared to all inflammatory biomarkers, observation of blood cells can be a simple alternative for the first triage and early identification of the infection" [1]. We agree that blood cell changes might be different in coronavirus disease-19 (COVID-19) patients with different stages of disease and severity. Focusing on the immunopathogenesis seen in COVID-19, stimulation of lymphocytes might occur and this might be similar to the pathological process seen in dengue. Regarding platelets, thrombocytopenia is a common problem and decreased platelet counts should be seen in peripheral blood smears [2]. Finally, there is another point that Ahnach et al. [1] did not mention. There might also be some underlying diseases or concurrent disorders in COVID-19 patients that could result in blood cell abnormalities. For example, there might be a concurrence between COVID-19 and parasitic infection, or the patient might have an underlying allergic problem related to the change of eosinophils $[3,4]$.

Keywords: COVID-19, Blood smear, Laboratory

Anahtar Sözcükler: COVID-19, Kan yayması, Laboratuvar
Ethics

Informed Consent: This is a letter to the editor discussing a published article and it is not a study or case report on human, animal, or other specimens. Therefore, it requires no consent form.

\section{Authorship Contributions}

Concept: R.M., V.W.; Design: R.M., V.W.; Data Collection or Processing: R.M., V.W.; Writing: R.M., V.W.

Conflict of Interest: No conflict of interest was declared by the authors.

Financial Disclosure: The authors declared that this study received no financial support.

\section{References}

1. Ahnach M, Ousti F, Nejjari S, Houssaini MS, Dini N. Peripheral blood smear findings in COVID-19. Turk J Hematol 2020;37:301-302.

2. Joob B, Wiwanitkit V. Hemorrhagic problem among the patients with COVID-19: clinical summary of 41 Thai infected patients. Clin Appl Thromb Hemost 2020;26:1076029620918308.

3. Lupia T, Corcione S, De Rosa FG. Giardiasis reactivation during severe SARSCoV-2 infection. Parasitol Int 2020;80:102241.

4. Yang JM, Koh HY, Moon SY, Yoo IK, Ha EK, You S, Kim SY, Yon DK, Lee SW. Allergic disorders and susceptibility to and severity of COVID-19: a nationwide cohort study. J Allergy Clin Immunol 2020;146:790-798. 